\title{
Underground Space of Saint-Petersburg as a Multicomponent System: Engineering Geological and Geotechnical Aspects of its Development
}

\author{
Regina Dashko' ${ }^{1}$ Ivan Alekseev² \\ Department of Hydrogeology and Engineering Geology, Geological Faculty, St. Petersburg Mining University, \\ Saint-Petersburg, Russia \\ E-mails: ${ }^{1}$ regda2002@mail.ru (corresponding author); ${ }^{2}$ alekseew.ivan@gmail.com
}

\begin{abstract}
The paper offers a complex approach to assess underground space as a multi-component system for its development and utilization. It is indicated that a geotechnical analysis of sandy and clayey soils of St. Petersburg needs to be carried out based on two models, i.e. one for a jointed and blocky environs and the other for fine-pored media. It has been established that chemical composition of the ground water in the city is characterized with a high content of alkaline-earth elements, which proves the intensive destruction of construction materials, as well as with presence of organic substances judging by the chemical oxygen demand (COD) and biological oxygen demand in 5 days (BOD5). For the first time ever, a microbiotic component has been distinguished which determines the following phenomena: 1) alteration of physical and mechanical properties of sandy and clayey soils; 2) development of flowing sand and thixotropic phenomena; 3) biocorrosion of various construction materials. It is stated that even consolidated morainic soils usually viewed as a safe foundation and media for structures of various applications are transformed into weak and easy-deformable materials characterized with low strength in conditions of intensive contamination.
\end{abstract}

Keywords: Underground space, sandy and clayey soils, microbiota, biochemical gases, buried structures.

Conference topic: Soil and rock investigation, design experiences and theoretical solutions.

\section{Introduction}

Development and use of urban underground space helps to solve a lot of social, economic and environmental issues. This being the case, current urban development patterns limit creation of utility lines, main transport routes and service spaces of various applications, which helps to significantly decrease material costs (extensive urban development). In many countries of the world underground space is viewed as a natural resource which use helps to preserve architectural and historical look of old cities with introduction of modern construction technologies, adequate to specific engineeringgeological and geotechnical conditions of the developed environment. Development of the underground space in Leningrad - St. Petersburg to the depth of over $100 \mathrm{~m}$ is related to construction of main line tunnels and underground stations of the city underground railway. Designs of high-rise buildings with the foundation pit depths exceeding 10-12 m were introduced in construction practice late in the $20^{\text {th }}$ Century - early in the $21^{\text {st }}$ Century.

Based on a substantial volume of complex investigations carried out in two recent decades, we have come to the conclusion that improving safety of underground space development and utilization in metropolitan cities (and most notably that of St. Petersburg) as well as in mining areas shall rely on its analysis as a multicomponent system with microbiota being an active element which activity determines negative transformation of sandy-clayey soils, changes in chemical composition of ground water, gas generation and corrosion of construction materials in the underground environment (Fig. 1).

\section{Methodology \\ Engineering-Geological Assessment and Analysis of Clayey Soils}

Engineering-geological and geotechnical analysis of soils in underground space of St. Petersburg requires a clear division into two groups of models. The first group includes single porosity soils, which in most cases are two-phase (mineral solids + water) and less frequently three-phase (mineral solids + water + gases). Stability assessment of surface facilities on clayey soils with single porosity should be based on possibility analysis of filtration consolidation. The latter as it follows from experiments and field observations carried out on different sites under the supervision of Professor R. E. Dashko is of restricted distribution and might occur only in soils with low content of clay fraction (Dashko, Kagan 1977; Dashko, Karpova 2015).

The second group of clay-models covers jointed and blocky media with individual blocks being finepored and micro-fissured. Jointing of clays has an adverse effect on their bearing capacity and permeability properties increasing them by $2-3$ orders as compared to the same parameters within an isolated block. Higher water permeability of the jointed rock mass involves a decrease in the waterproof properties of the confining layers which should be taken into account in designing and operation of underground facilities. 

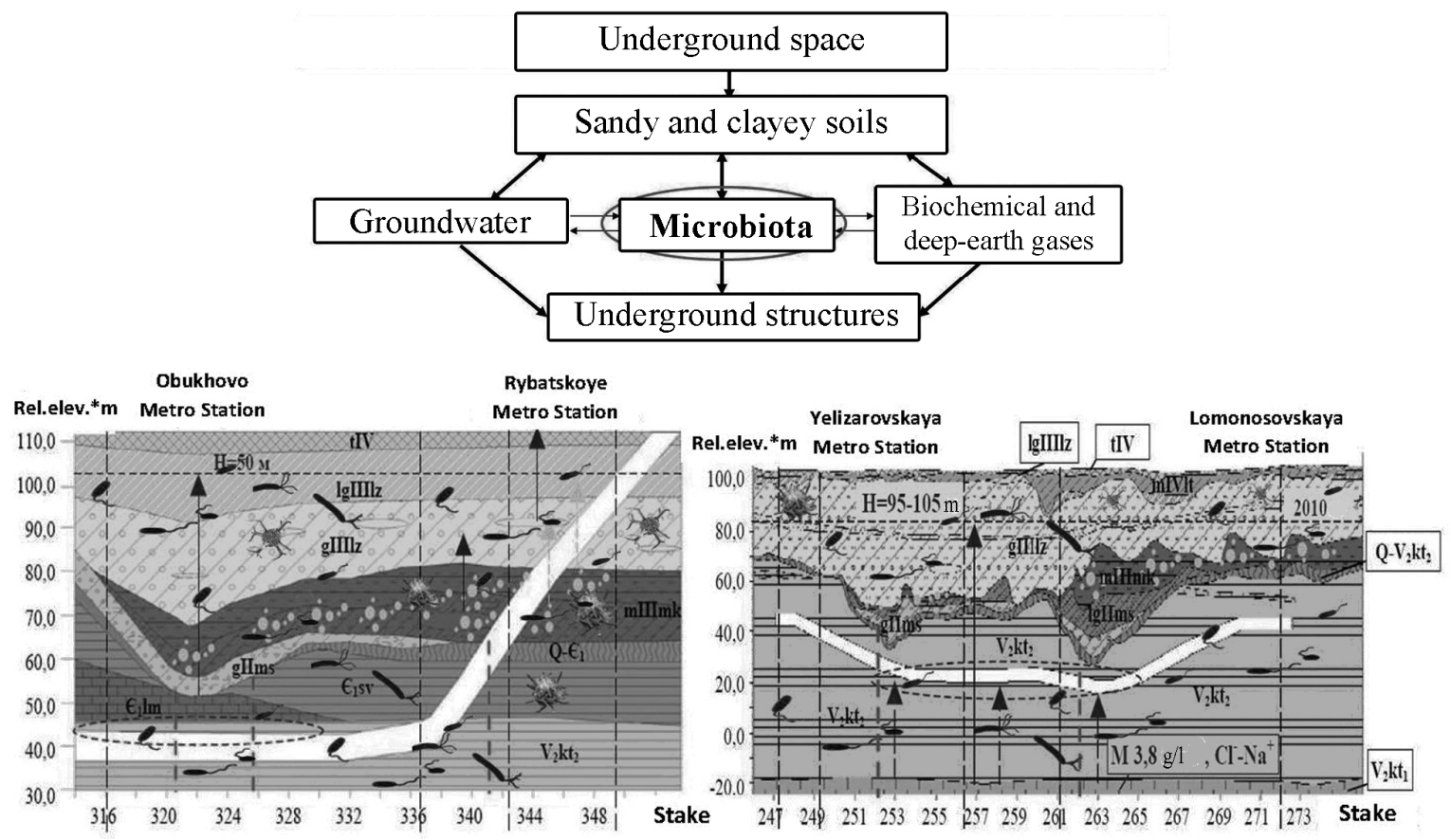

Fig. 1. Underground space of St. Petersburg as a multi-component system illustrated by cross-sections along main line tunnels of St. Petersburg metro (south-eastern lines)

Geology of St. Petersburg is mostly represented with Quaternary sediments. Recent post-glacial, lateglacial and partially morainic variations feature the single porosity media, while bed clays (preQuaternary sediments), due to specific features of their geological formation, shall be analyzed as fissured and blocky environs. This category includes original LowCambrian and Upper Vendian clays as well as sandstones of similar geologic age that contain confined aquifers characterized with higher mineralization.

According to the classification proposed by V. D. Lomtadze Vendian and Cambrian clays are attributed to clayey varieties of high lithification degree and are considered as a uniform formation characterized with low variability in composition, condition and properties both laterally and depth-wise. When applied in civil construction, such an approach results in incorrect

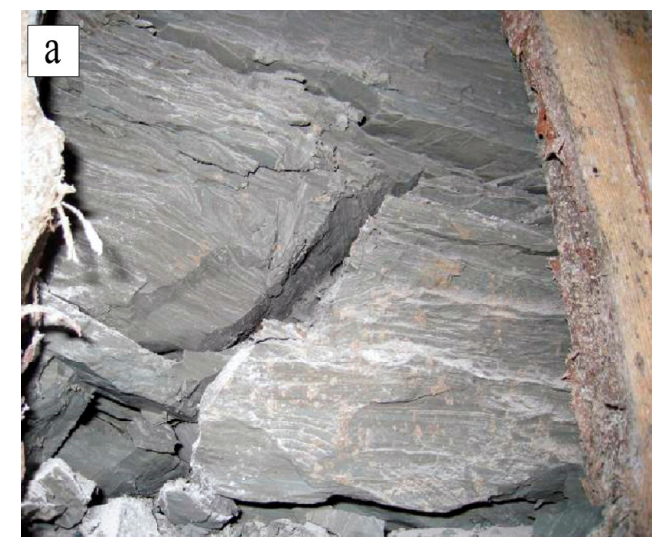

geotechnical assessment of these sediments analysed as base or medium for constructions.

Research activities carried out for the recent 30 years made it possible to describe these clays as jointed and blocky media with pronounced depth-wise zoning structure outside of tectonic zones (Fig. 2).

Formation of joints is related to the action of tectonic and glacial tectonic forces, paleoweathering processes during the geological periods when these clays (Upper Vendian and Low Cambrian) were exposed to the daylight surface in the area of St. Petersburg about $70 \mathrm{mln}$. years ago. During the glacial period these sediments were subjected to a number of loading-unloading cycles which resulted in development of joints due to elastic resistance (during unloading), ice-breaking and frost splitting. Thus, the maximum decompaction zone in the Vendian clays is $40-50 \mathrm{~m}$, while for the Low

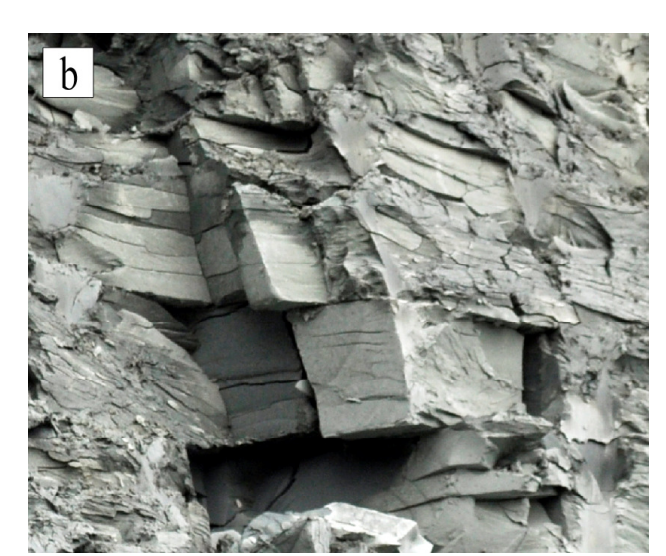

Fig. 2. Clayey varieties: a - Upper Kotlin clays (in underground workings); b - Lower Cambrian blue clays (in open pit walls) 

geotechnical aspects of its development

Cambrian blue clays it is equal to $20-25 \mathrm{~m}$. Tectonic forces promoted development of tectonic jointing that is characterized with joint sets of North-Western, NorthEastern, sublatitudinal and submeridional strikes with rather steep dip angles.

High degree of clay disintegration in the upper part of the cross-section predetermined high moisture content of clays associated with processes of additional clay hydration in their decompaction zone down to the depths where the soil dead load stress $\left(\sigma_{z}\right)$ is close to their swelling pressure.

It is important to note that current engineeringgeological survey practices, including those of St. Petersburg region, do not take into account presence of joints in lithified clayey varieties. However, disintegration of these sediments is of key importance in assessment of their: 1) in situ permeability; 2) strain and shear strength properties; 3) bearing capacity; 4) non-uniformities in deformation development; 5) the character of stress distribution in structure bases; 6) possibilities of descending and/or ascending water migration through argillaceous confining beds. It should be noted that permeability of clayey sediments should be taken into account in designing of structures in areas where confined aquifers with various degrees of mineralization and aggressiveness towards underground structures are present as well as in construction of domestic and industrial waste landfills in such clays.
As the result of experimental field studies aimed to assess permeability of Upper Vendian clayey varieties it was established that presence of joints increases their insitu permeability by several orders, while in laboratory conditions it does not exceed $10^{-5}-10^{-7} \mathrm{~m} /$ day.

Disintegration of clayey soils also impacts their strength and strain properties. Thus, studies of mechanical properties of Vendian clays revealed logical increase in their strength and decrease in their compressibility with increasing depth. However, this regularity is not applicable to tectonic zones where strength and strain properties of clayey varieties are changing over a wide range of values (Table 1).

Jointing of clayey soils also affects the stress distribution within the geologic formation. The key parameters that define stress distribution in stratified or blocky medium are as follows: joint set strike; geometry of blocks that made up the formation and their relative position, characteristics of the contact surfaces; shear strength along the contact surfaces; strain and strength properties of the block material; character of load transferred to the base; the number of separate blocks within the bearing area of the structure base.

Disintegration and stratification of soils defines asymmetric distribution of normal stresses $\left(\sigma_{z}\right)$ within the active zone of the construction, which leads to nonuniform deformation (settlements) in basement soils (Fig. 3).

Table 1. Comparison of strength and strain properties of blue clays based on triaxial test results (Dashko 2014)

\begin{tabular}{|c|c|c|c|c|c|}
\hline \multirow{2}{*}{\multicolumn{2}{|c|}{ Location of sampling points }} & \multirow{3}{*}{$\begin{array}{c}\begin{array}{c}\text { Depth below layer } \\
\text { superface, } \mathrm{m}\end{array} \\
55.0-65.0\end{array}$} & \multicolumn{2}{|c|}{ Strength properties } & \multirow{3}{*}{$\begin{array}{c}\begin{array}{c}\text { General deformation } \\
\text { modulus } E_{0}, \mathrm{MPa}\end{array} \\
8.0-16.0\end{array}$} \\
\hline & & & C. $\mathrm{MPa}$ & $\varphi$, degr. & \\
\hline \multirow{3}{*}{$\begin{array}{c}\text { Construction site of } \\
\text { 'Okhta Center' Multi-Purpose } \\
\text { Complex, St. Petersburg, Russia }\end{array}$} & \multirow{3}{*}{$\begin{array}{l}\text { Within tectonic } \\
\text { zones }\end{array}$} & & $0.12-0.25$ & $10-14$ & \\
\hline & & $65.0-85.0$ & $0.09-0.28$ & $11-16$ & $20.1-52.0$ \\
\hline & & $85.0-105.0$ & $0.08-0.30$ & $14-18$ & $22.3-113.1$ \\
\hline \multirow{3}{*}{$\begin{array}{c}\text { Construction site of } \\
\text { 'Lakhta Center' Multi-Purpose } \\
\text { Complex, St. Petersburg, Russia }\end{array}$} & \multirow{3}{*}{$\begin{array}{l}\text { Outside tectonic } \\
\text { zones }\end{array}$} & $24.0-24.2$ & $0.06-0.08$ & $7-11$ & $10.2-22.7$ \\
\hline & & $51.0-62.4$ & $0.15-0.31$ & $20-24$ & $24.4-100.1$ \\
\hline & & $81.0-90.4$ & $0.20-0.55$ & $22-27$ & $35.2-180.1$ \\
\hline
\end{tabular}

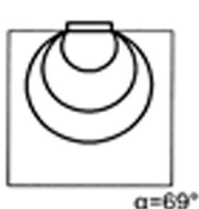

$a=69^{\circ}$
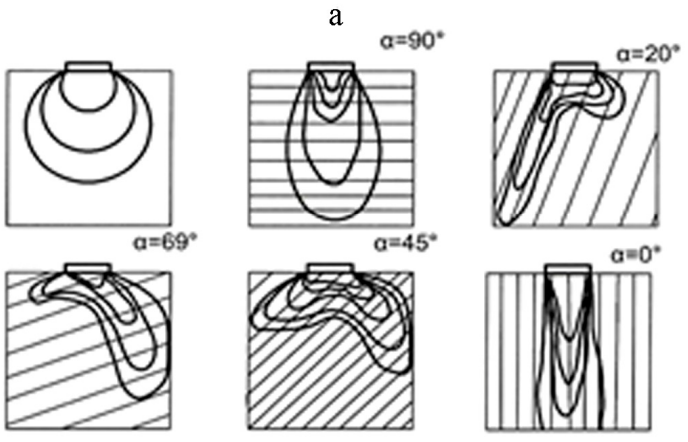

Fig. 3. Isobars of compressive stresses $\sigma z$, obtained on models (a) and calculated (b), $\alpha-$ angles of joints or layers (as per R. Goodman) 


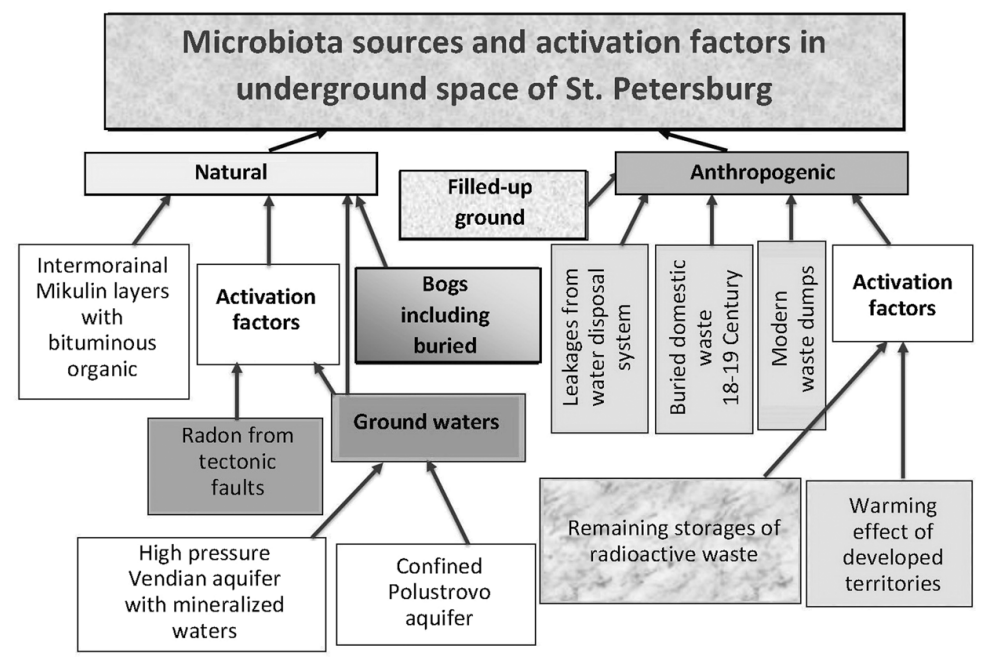

Fig. 4. Sources of underground microbiota and factors contributing to intensification of its activity in underground space of St. Petersburg

\section{Ground water assessment}

The second most important component in the underground space is the ground water. In efforts to improve safety of development and utilization of urban underground space as well as construction and operation of structures various applications, the action of ground waters is viewed from the following standpoints: 1) creation of the stress-and-strain behavior of the soil layer especially in conditions of changing hydrodynamic modes of highly-pressurized aquifers (with the pressure heads of over $100 \mathrm{~m}$ ); 2) ascending or descending groundwater leakages through jointed and blocky confining layers with a subsequent assessment of physicochemical and chemical interaction between ground water and clayey blocks; 3) action of mineralized and contaminated water on clayey and sandy soils and construction materials of various ages. Aggressive action of the ground water can be assessed in terms of specific oxidation-reduction and acid-base conditions, biochemical processes of microbial metabolites formation including organic and mineral acids, albumen (proteins) and gases.

\section{Subsurface microbiota}

The third component is subsurface microbiota, which behaves as one of the active parts of underground environment. Alongside with the adverse effect, it is also important to mention its positive role in the processes of ground water self-regulation and self-purification, first of all, from petroleum products as well as other organic compounds. Natural and anthropogenic microbiocenoses that can be used in treatment of natural and effluent waters contaminated with petroleum products were identified. However, activity of microorganisms in water-saturated soil layers leads to accumulation of microbial mass consisting of live and dead cells and their metabolites of both protein-based and non-protein nature, which forms biofilms on grains of dispersive soils
(Dashko 2014; Dashko, Karpova 2015). Microbiological studies performed in subsurface environs of St. Petersburg and the Leningrad Region helped to identify the main natural and anthropogenic sources of underground microbiota as well as factors contributing to intensification of its activity (Fig. 4).

\section{Discussion}

Analysing transition of constructions with various applications built on clayey soils to pre-emergency and emergency state

Presence of joints in clayey soils predetermined their depth-related zonal structure that is primarily reflected by the block sizes, which dimensions are naturally increasing with depth outside of zones affected by tectonic faults (Table 2).

Analysis of construction and operation of civil buildings based on jointed Lower Cambrian Clays shows that underestimation of the disintegration character of the formation as well as its high sensitivity to contamination due to seepage of various effluent into the jointed stratum promotes transition of such buildings to pre-emergency and emergency state.

This phenomenon can be exemplified by the decay dynamics of a 9-storey residential building based on a girder footing built in late 20th Century in the Pushkinskiy District of St. Petersburg. Design and stability calculations for this construction were made without account of the jointed character of the blue clays underlying the building. By the time construction reached the 6th storey, differential settlement was registered to be increasing. Upon completion of the construction, uneven displacement of clays was recorded along the entire contour of the building which resulted in its tilt by 27 degrees. As the consequence, the building was demolished as being beyond repair. 
Table 2. Variations in depth-related fracturing degree and moisture content of Upper Kotlin and blue clays (Dashko 2014)

\begin{tabular}{|c|c|c|c|c|}
\hline Distinguished zones & $\begin{array}{l}\text { No. of } \\
\text { layers }\end{array}$ & $\begin{array}{l}\text { Depth from clays } \\
\text { superface, } m\end{array}$ & Block size, $\mathrm{m}$ & $\begin{array}{l}\text { Variation range of } \\
\text { moisture content, \% }\end{array}$ \\
\hline \multicolumn{5}{|c|}{ Upper Kotlin Vendian Clays } \\
\hline \multirow{2}{*}{$\begin{array}{c}\text { I } \\
\text { Variable moisture content and density }\end{array}$} & 1 & $0-20$ & $0.10-0.50$ & $12-23$ \\
\hline & 2 & $20-40$ & $0.50-0.70$ & $10-20$ \\
\hline \multirow{3}{*}{$\begin{array}{c}\text { II } \\
\text { Quasi-constant moisture content and density }\end{array}$} & 3 & $40-60$ & $0.70-1.0$ & $10-19$ \\
\hline & 4 & $60-75$ & 1.2 & $10-17$ \\
\hline & 5 & $>75$ & $>1.2$ & $9-15$ \\
\hline \multicolumn{5}{|c|}{ Lower Cambrian blue clays } \\
\hline \multirow{3}{*}{$\begin{array}{l}\text { I } \\
\text { Variable moisture content and } \\
\text { density }\end{array}$} & 1 & $0-3$ & $0.08-0.25$ & $\begin{array}{c}23-28 * \\
25-32 * * \\
\end{array}$ \\
\hline & 2 & $3-10$ & $0.25-0.40$ & $\begin{array}{l}21-25 \\
22-29\end{array}$ \\
\hline & 3 & $10-20$ & $0.38-0.60$ & $\begin{array}{l}17-21 \\
19-26\end{array}$ \\
\hline \multirow{3}{*}{$\begin{array}{c}\text { II } \\
\text { Quasi-constant moisture content and density }\end{array}$} & 4 & $20-30$ & $0.40-0.85$ & $\begin{array}{l}16-20 \\
18-24\end{array}$ \\
\hline & 5 & $30-40$ & $0.60-0.90$ & $\begin{array}{l}16-19 \\
17-23\end{array}$ \\
\hline & 6 & $>40$ & $1.0-1.40$ & $\begin{array}{l}15-18 \\
17-23\end{array}$ \\
\hline
\end{tabular}

Notes: * variations of the parameter value outside tectonic zones; ** - within tectonic zones.

Expert evaluation performed by Prof. R. E. Dashko with due account for the influence of jointing on the bearing capacity of clayey variations demonstrated that samples of blue clays subjected to triaxial compression fail as quasi-plastic variations without forming a plane of failure. Recalculation of the soil bearing capacity with the foundation depth $h_{f}=1.5 \mathrm{~m}$ and its width of $2 \mathrm{~m}$ indicated that the building pressure $\left(\mathrm{p}_{\mathrm{b}}\right)$ exceeds the second critical pressure $\left(p_{2}\right): p_{2}=0.24 \mathrm{Mpa}<p_{b}=$ $0.27 \mathrm{MPa}$, which explains clay uplift from above the building (Dashko 1987).

The calculation of $p_{2}$ was made using the L. Prandtl equation: $p_{2}=5.14 \mathrm{c}+\gamma \mathrm{h}_{\mathrm{f}}$ using the cohesion value $(c=0.085 \mathrm{MPa})$, obtained as the result of triaxial compression tests of large-size samples and adjusted with the structure attenuation factor $(\lambda=0.48)$ that takes into account clay jointing $(\mathrm{c}=0.085 \cdot 0.48=0.041 \mathrm{MPa}$; $\gamma$ - spec. gravity $\left.-20 \mathrm{kH} / \mathrm{m}^{3}\right)$.

Another example of transition into a critical condition is a 9-storey residential building that was in operation in the Town of Nikolskoye (Leningrad Region). This construction was also based on jointed Lower Cambrian clays. Development of differential settlement of the building at the early stages of its operation damaged pipes of the water disposal system. Inflow of sewage effluents into the disintegrated clayey formation of the structure base zone and its subsequent adverse transformation expressed in decompaction of clayey soil due to swelling and gradual loss of bearing capacity during the next 5 years of operation resulted in building deformation, i.e. skew, creep of floor structures and transition of the building into an emergency condition. The building was dismantled. It should be noted that during the dynamic load test of the foundation soils, the probe penetrated to the depth of $8.0 \mathrm{~m}$ under its own weight, which witnesses transformation of clays and their transition to weak clays category. Laboratory tests helped to establish that due to the impact of sewage effluents the shear strength of the clayey soils dropped to the minimum values of $<0.05 \mathrm{MPa}$ (their jointing not being taken into account).

Another example is the failure of linings in a shallow transport tunnel that was driven through a formation of blue clays. Performed engineering surveys failed to study a critical factor, i.e. impact of undercutting a lowgradient slope within an old landslide tongue made up of disintegrated blue clays. This resulted in revival of landslide dislocations and deformation of the tunnel walls. The internal friction angle of blue clays was $4^{\circ}$, while cohesion of the tested samples in triaxial tests was varying within $0.034-0.046 \mathrm{MPa}$, and with account for macro-fissuring it stood at $0.017-0.023 \mathrm{MPa}$.

\section{Ground water impact on long-term stability of constructions}

Ground water plays a critical role in assessment of buildings stability. Composition and physicochemical 

geotechnical aspects of its development

properties of ground water is influenced not only by atmospheric precipitation and presence of buried or active bogs, but also by man-caused factors, e.g. leaks from water disposal systems, liquid components from waste dumps, cemeteries, etc. A complex analysis of ground water within the historical part of St. Petersburg helped to establish that specific features of its chemical composition determine stability of foundation structures, including the leaching degree of limestone rubble and brick mortar of foundations of ancient buildings. Thus, composition of ground water is characterized with high content of alkaline-earth elements, i.e. $\mathrm{Ca}^{2+}-92.3-$ $420.8 \mathrm{mg} / \mathrm{dm}^{3} ; \mathrm{Mg}^{2+}-25.4-199.2 \mathrm{mg} / \mathrm{dm}^{3}$, the chemical oxygen demand (COD) is ranging from 20 to $120 \mathrm{mgO}_{2} / \mathrm{dm}^{3}$ (Dashko 2014).

The Vendian aquifer system, which currently features high pressure heads of over $100 \mathrm{~m}$, plays a key role in securing stability of high-rise buildings and deep-laid underground constructions in St. Petersburg. Ground waters of the Vendian system are characterized with chloride and sodium composition and high mineralization (from 2.5 to $3.5 \mathrm{~g} / \mathrm{dm}^{3}$, less frequently higher). The impact of the Vendian aquifer system needs to be taken into consideration in 1) construction of high-rise buildings, use of deep excavations and pile foundations with slab foundation grille; 2) in excavation and operation of Metro tunnels of various depths. It should also be noted that in construction of a pile field with the pile length from 60 to $80 \mathrm{~m}$, the confined Vendian aquifer system might be present in the bottom zone of the structure, which can promote attenuation of the pile mantle friction due to upward groundwater leakage and lead to a decrease in their load capacity.

It is important to note that no impact of confined Vendian ground waters or their chemistry on long-term stability of main line tunnels have ever been analyzed in designing metro lines in Upper Kotlin clays. Research carried out at St. Petersburg State Mining University revealed that upward leakage of chloride sodium groundwater from this aquifer system through the jointed layer of clays causes damage to cast-iron and reinforced concrete linings not only by chemical reactions, but also as the result of biochemical processes.

\section{Geotechnical assessment of microbial constituents and their impact on components of underground environs}

Microbiotic activity can be traced throughout the sedimentary cover of St. Petersburg, which thickness varies from 185 to $240 \mathrm{~m}$. Accumulation of microbial mass in sands leads to decreasing of their water return almost to zero levels and permeability coefficient down to $10^{-3}$ $10^{-4} \mathrm{~m} /$ day combined with the action of high head gradients and sand transformation into flowing sands. Clayey soils in case of their significant saturation with microbiotic components will transform into unstable state due to decreasing strength.

The fourth, gaseous component of the underground environs, and first of all the gas of biochemical genesis, plays a special role in securing long-term stability of constructions in St. Petersburg. In terms of their solubility degree, biochemical gases can be divided into very and marginally soluble. Biochemical generation of gases and primarily marginally soluble gases $\left(\mathrm{CH}_{4}, \mathrm{~N}_{2}, \mathrm{H}_{2}\right)$, enrich dispersive sediments with "hard" gas bubbles, which diameter is significantly lesser than the soil pore size. Such a solid gas phase acts as a ball bearing decreasing the internal friction of soils and thus accelerating transformation of sands into the "heavy" fluid state. Most part of the water-saturated sand layer in the upper part of the city's underground environs is characterized as flowing sands which fails to be determined by Cone Penetration Tests. As it was previously noted, if affected by microbial activity, clayey soils behave as quasiplastic varieties in lack of filtration consolidation and decrease in their strength in time.

Accumulation of marginally soluble gases leads to changes in the stress-and-strain behavior due to formation of gas-dynamic pressure which promotes gas outburst into boreholes, foundation pits, and underground excavations as well as spontaneous ignition of methane. The impact of gas-dynamic pressure was assessed during investigations of the main line tunnels constructed above the gas-generating Mikulin sediments rich in bituminous organic substances where rich biotic community was discovered. Development of high gasdynamic pressure resulted in significant elevational deformation of the tunnel structures and formation of cracks.

Generation of soluble gases, i.e. hydrogen sulphide $\left(\mathrm{H}_{2} \mathrm{~S}\right)$ and carbon dioxide $\left(\mathrm{CO}_{2}\right)$, in the city underground space is very typical of its historical part and can be clearly traced down to the depths of $25 \mathrm{~m}$, which is proved by presence of black hydrotroilite stains and the stink damp $\left(\mathrm{H}_{2} \mathrm{~S}\right)$ smell.

Presence of organic substances of abiotic and biotic genesis as well as very soluble gases $\left(\mathrm{H}_{2} \mathrm{~S}\right.$ и $\left.\mathrm{CO}_{2}\right)$ significantly enhances aggressiveness of underground media towards construction materials. Presence of organic content in ground waters results in decreasing of the acid-base potential. Solidification of concretes is not observed in conditions of low $\mathrm{pH}$ values. Thus, in one of projects during construction of cast-in-place piling to create a barrier for the deep construction pit, the concrete did not solidify well which resulted in emergency situations, i.e. ground water breakthrough into the construction pits and their flooding.

Besides, it was observed that destruction of carbonate rock (basement brick mortar), ferrous metals (underground utility lines, beams, bars, concrete reinforcement) takes place in zones characterized with active microbial activity and low $\mathrm{pH}$ values. The velocity of corrosion process accelerated by microbial activity is several times higher that that of chemical and physiochemical corrosion. Thus, it is requited to make provisions to decrease in the destructive effect of microorganisms in zones of active microbial activity. 


\section{Conclusions}

Investigations of the underground space performed in order to secure long-term stability of constructions help to make the following conclusions.

1. Geotechnical and engineering-geological assessment of underground space shall be based on a complex approach to it as a multi-component system comprising sandy and clayey soils, waters of confined and unconfined aquifers, microbiota, gases of various genesis, underground structures, all of which closely interact with each other.

2. Clayey sediments in subsurface geology of St. Petersburg that are used as either environs or foundations of constructions shall be treated as jointed and blocky or fine-pored media.

3 . Ground water characterized with various hydrodynamic and hydrochemical regimes impacts the stressand-strain behavior of the soil layer creating ascending or descending groundwater leakages through jointed confining layers and having an aggressive action on construction materials. Thus, an account of redox conditions based on Eh and $\mathrm{pH}$ values ought to be employed in situ only. Particular attention should be given to reducing conditions with a presence of $\mathrm{H}_{2} \mathrm{~S}$ and $\mathrm{CO}_{2}$, which are considered to be the most dangerous.

4. As part of geotechnical surveys, it is required to perform studies of microbiotic components with due account for its impact on transformation of watersaturated dispersive soils properties due to occlusion and accumulation of microbiota metabolites, increase in aggressive action of ground waters in presence of easily biochemically dissolvable gases, i.e. $\mathrm{H}_{2} \mathrm{~S}$ и $\mathrm{CO}_{2}$, changes in the stress-and-strain behavior due to deposition of slightly-soluble gases as well as creation of biocorrosive properties of the underground environs. All of this is currently missing in Russian standards of structures design.

\section{Funding}

This work was supported by the Russian Science Foundation [grant number 16-17-00117].

\section{Disclosure statement}

Authors declare: financial support from the Russian Science Foundation for the submitted work; no financial relationships with any organisations that might have an interest in the submitted work in the previous three years; no other relationships or activities that could appear to have influenced the submitted work.

\section{References}

Dashko, R. E. 1987. Mehanika gornyh porod: textbook. Moscow, Russia: Nedra.

Dashko, R. E. 2014. Osobennosti razrushenija podzemnyh konstrukcij arhitekturno-istoricheskih pamjatnikov pri agressivnom vozdejstvii komponentov podzemnoj sredy Sankt-Peterburga, in International Conference on Experience of Preserving Cultural Heritage: Challenges in Stone Restoration, 17-19 September 2014, Peterhof, Russia, 76-87.

Dashko, R. E. 2015. Inzhenerno-geologicheskij analiz $i$ ocenka vodonasyshhennyh glinistyh porod kak osnovanija sooruzhenij. St. Petersburg, Russia: Institut "PI 'Georekonstruktsiya",

Dashko, R. E.; Vlasov, D. Yu.; Shidlovskaya A. V. 2014. Geotehnika i podzemnaja mikrobiota. St. Petersburg, Russia: Institut "PI 'Georekonstruktsiya".

Dashko, R. E.; Kagan, A. A. 1977. Mehanika gruntov v inzhenerno geologicheskoj praktike. Moscow, Russia: Nedra.

Dashko, R. E.; Karpova, Ya. A. 2015. Sovershenstvovanie podhodov $\mathrm{k}$ ocenke gidrogeologicheskih issledovanij $\mathrm{v}$ sostave inzhenernyh izyskanij na territorijah megapolisov (na primere Sankt-Peterburga), in $15^{\text {th }}$ Session of RAS Scientific Council on Geoecological, Engineering-Geological and Hydrogeological Issues: Sergeevskie chtenija, 19-20 March 2015, Moscow, Russia, 338-343. 